\title{
Parental age and risk of genetic syndromes predisposing to nervous system tumors: nested case-control study
}

This article was published in the following Dove Press journal:

Clinical Epidemiology

\section{Maral Adel Fahmideh' \\ Giorgio Tettamanti' \\ Catharina Lavebratt ${ }^{2}$ \\ Mats Talbäck' \\ Tiit Mathiesen ${ }^{3,4}$ \\ Birgitta Lannering ${ }^{5}$ \\ Kimberly J Johnson 6,7 \\ Maria Feychting'}

'Unit of Epidemiology, Institute of Environmental Medicine, Karolinska Institutet, Stockholm, Sweden;

${ }^{2}$ Neurogenetics Unit, Department of Molecular Medicine and Surgery, Karolinska Institutet, Center for Molecular Medicine, Karolinska University Hospital, Stockholm, Sweden; ${ }^{3}$ Department of Clinical Neuroscience, Karolinska Institutet, Stockholm, Sweden; ${ }^{4}$ University of Copenhagen, Copenhagen, Denmark; ${ }^{5}$ Department of Pediatrics, University of Gothenburg, Gothenburg, Sweden; ${ }^{6}$ Brown School, Washington University in St Louis, St Louis, MO, USA; ${ }^{7}$ Department of Pediatrics, School of Medicine, Washington University in St Louis, St Louis, MO, USA
Correspondence: Maral Adel Fahmideh Unit of Epidemiology, Institute of Environmental Medicine, Karolinska Institutet, Nobels väg 13, SE-I7I 77 Stockholm, Sweden

Tel +46852483954

Email maral.adel.fahmideh@ki.se
Purpose: Phacomatoses are genetic syndromes that are associated with increased risk of developing nervous system tumors. Phacomatoses are usually inherited, but many develop de novo, with unknown etiology. In this population-based study, we investigated the effect of parental age on the risk of phacomatoses in offspring.

Patients and methods: The study was a population-based nested case-control study. All individuals born and residing in Sweden between January 1960 and December 2010 were eligible for inclusion. Using the Patient Register, 4625 phacomatosis cases were identified and further classified as familial or nonfamilial. Ten matched controls per case were randomly selected from the eligible population. Data were analyzed using conditional logistic regression. Analyses were conducted for neurofibromatosis alone $(\mathrm{n}=2089)$ and other phacomatoses combined $(\mathrm{n}=2536)$.

Results: Compared with offspring of fathers aged 25-29 years, increased risk estimates of nonfamilial neurofibromatosis were found for offspring of fathers aged 35-39 years (odds ratio $[\mathrm{OR}]=1.43$ [95\% CI 1.16-1.74]) and $\geq 40$ years ( $\mathrm{OR}=1.74$ [95\% CI 1.38-2.19]). For other nonfamilial phacomatoses, the risk estimate for offspring of fathers aged $\geq 40$ years was OR $=1.23$ (95\% CI 1.01-1.50). Paternal age was not associated with familial phacomatoses, and no consistent association was observed with maternal age.

Conclusion: The findings show a consistent increase in risk of de novo occurrence of phacomatoses predisposing to nervous system tumors in offspring with increasing paternal age, most pronounced for neurofibromatosis, while maternal age did not seem to influence the risk. These findings suggest an increasing rate of new mutations in the $N F 1$ and $N F 2$ genes in spermatozoa of older fathers. Keywords: phacomatoses, nervous system tumor predisposition syndromes, parental age, registry, neurofibromatosis

\section{Introduction}

Genetic syndromes are established risk factors for various diseases, including cancer. ${ }^{1}$ Phacomatoses are genetic syndromes with increased cancer susceptibility and are characterized by multiple hamartomas of the central and peripheral nervous system, eye, skin, and viscera. ${ }^{2}$ There are several known phacomatoses that predispose individuals to development of nervous system tumors (Table 1), of which neurofibromatosis type 1 and type 2 (NF1 and NF2) and tuberous sclerosis complex (TSC) are the most common.,4

The birth prevalence of NF1, NF2, and TSC is, approximately, 1 in $3000,{ }^{5} 1$ in $35000,{ }^{3,5}$ and 1 in $10000,,^{3,6}$ respectively. They are autosomal dominant disorders; however, they develop de novo in a large proportion of patients with no previous family history of the disease. It is estimated that $\sim 50 \%$ of NF1 and NF2 are de novo 
Table I Genetic syndromes predisposing to nervous system tumors

\begin{tabular}{|c|c|c|c|c|c|}
\hline Syndrome (OMIM) & $\begin{array}{l}\text { ICD-9/ICD- } \\
10\end{array}$ & Gene & Locus & Inheritance & Nervous system tumors \\
\hline $\begin{array}{l}\text { Neurofibromatosis type I } \\
(162200)\end{array}$ & 237H/Q85.0 & NFI & $|7 q| 1.2$ & $A D$ & $\begin{array}{l}\text { Spinal neurofibromas, optic gliomas, } \\
\text { astrocytomas, meningioma, malignant } \\
\text { peripheral nerve sheath tumors }\end{array}$ \\
\hline $\begin{array}{l}\text { Neurofibromatosis type } 2 \\
(101000)\end{array}$ & 237H/Q85.0 & NF2 & $22 q \mid 2.2$ & $A D$ & $\begin{array}{l}\text { Schwannoma, meningioma, ependymoma, } \\
\text { astrocytoma }\end{array}$ \\
\hline $\begin{array}{l}\text { Schwannomatosis } \\
(16209 \mid)\end{array}$ & 237H/Q85.0 & NF2/SMARCBI/? & $22 q|2.2 / 22 q| \mid .23 / ?$ & $A D$ & Schwannoma \\
\hline $\begin{array}{l}\text { Tuberous sclerosis } \\
\text { complex }(191100)\end{array}$ & 759F/Q85.I & TSCI/TSC2 & $9 q 34.13 / 16 p / 3.3$ & $A D$ & $\begin{array}{l}\text { Ependymoma, giant cell astrocytoma, retinal } \\
\text { astrocytoma }\end{array}$ \\
\hline Li-Fraumeni (I5I623) & 759/Q85 & TP53/CHEK2 & |7p|3.| & $A D$ & Astrocytoma, medulloblastoma \\
\hline $\begin{array}{l}\text { Gorlin (basal cell nevus } \\
\text { syndrome) }(109400)\end{array}$ & 759/Q85 & PTCHI/PTCH2/SUFU & $\begin{array}{l}9 q 22.32 / 1 p 34.1 / \\
10 q 24.32\end{array}$ & $A D$ & Medulloblastoma \\
\hline Turcot (276300) & 759/Q85 & $\begin{array}{l}\text { APC/hMLHI/hPMS2/ } \\
\text { hMSH2/hMSH6 }\end{array}$ & $\begin{array}{l}5 q 22.2 / 3 p 22.2 / 7 p 22 \\
1 / 2 p 21-p 16 / 2 p 16.3\end{array}$ & $\mathrm{AR}$ & $\begin{array}{l}\text { Medulloblastoma, astrocytoma, glioblastoma } \\
\text { multiforme }\end{array}$ \\
\hline Cowden (I58350) & 759/Q85 & PTEN & $10 q 23.31$ & $A D$ & Astrocytoma, meningioma \\
\hline $\begin{array}{l}\text { Rubinstein-Taybi } \\
(180849)\end{array}$ & 759/Q85 & CREBBP & $16 p \mid 3.3$ & $A D$ & $\begin{array}{l}\text { Oligodendroglioma, medulloblastoma, } \\
\text { neuroblastoma, meningioma }\end{array}$ \\
\hline $\begin{array}{l}\text { Multiple hamartomas } \\
(601728)\end{array}$ & 759/Q85 & PMS2/PTEN & $7 p 22.2 / 10 q 23.31$ & $A D$ & $\begin{array}{l}\text { Oligodendroglioma, astrocytoma, meningioma, } \\
\text { glioblastomas }\end{array}$ \\
\hline $\begin{array}{l}\text { Ataxia telangiectasia } \\
(208900)\end{array}$ & $334 \mathrm{~W} / \mathrm{G} I \mathrm{I} .3$ & ATM & I Iq22.3 & $\mathrm{AR}$ & Medulloblastoma, gliomas \\
\hline $\begin{array}{l}\text { von Hippel-Lindau } \\
\text { (I } 93300)\end{array}$ & 759G/Q85.8C & VHL/CCNDI & $3 p 25.3 / I|q| 3.3$ & $A D$ & Hemangioblastoma \\
\hline Carney complex (I60980) & 759/Q85 & PRKARIA & $17 q 24.2$ & $A D$ & Melanotic schwannoma \\
\hline $\begin{array}{l}\text { Melanoma-astrocytoma } \\
\text { (I 55755) }\end{array}$ & 759/Q85 & $C D K N 2 A$ & $9 p 21.3$ & $A D$ & $\begin{array}{l}\text { Astrocytoma, medulloblastoma, glioblastoma } \\
\text { multiforme, ependymoma, glioma, } \\
\text { meningioma, acoustic neurilemmoma }\end{array}$ \\
\hline $\begin{array}{l}\text { Hereditary } \\
\text { retinoblastoma }(180200)\end{array}$ & 759/Q85 & $R B I$ & $|3 q| 4.2$ & $A D$ & Retinoblastoma \\
\hline
\end{tabular}

Abbreviations: OMIM, Online Mendelian Inheritance in Man; ICD, International Statistical Classification of Diseases and Related Health Problems, Ninth and Tenth Revisions; $A D$, autosomal dominant; $A R$, autosomal recessive.

occurrences, while for TSC, the majority of cases are de novo ( $65 \%-85 \%),{ }^{3,4}$ Furthermore, it is known that some of the de novo mutations occur in cells after fertilization, resulting in mosaicism, eg, $\sim 30 \%$ of de novo NF 2 cases are due to mosaic mutations, ${ }^{3}$ while mosaic NF1 occurs less commonly, with birth prevalence of 1 in $36000 .^{4}$

There is some inconclusive evidence on the association between perinatal factors, including advanced parental age, and phacomatoses in offspring, which is most likely due to the increased risk of new germ line mutations..$^{7-9}$ The available studies are very few, are small, and focus on the association between parental age and risk of NF1 in offspring. ${ }^{7,8,10,11}$ In addition, it has been shown that perinatal factors, such as advanced parental age, are associated with various types of pediatric cancer, including nervous system tumors. ${ }^{12-14}$ Therefore, the observation of an increased risk of nervous system tumors related to advanced parental age, as well as related to genetic syndromes, led to the hypothesis that nonfamilial genetic syndromes may be associated with advanced parental age. Hence, in this study, we investigated the effect of parental age on the risk of being born with a genetic syndrome associated with the occurrence of nervous system tumors.

\section{Patients and methods Study subjects and procedures}

\section{Study population}

The study is designed as a case-control study nested within the Swedish population. The eligible population includes individuals who were born and resident in Sweden at any time during the period between 1 January 1960 and 31 December 2010 with information available about parental age for both biological parents. ${ }^{15}$ Informed consent was not required for this study since it was register based. The study was approved by the Regional Ethical Review Board in Stockholm, and the National Board of Health and Welfare assessed patient confidentiality before making deidentified and anonymous data available for analyses.

\section{Case identification}

Cases were identified through linkage of the population to the Patient Register, using the unique personal identifier 
assigned to each Swedish resident. The Patient Register was initiated in 1964 and contains information on diagnostic codes and surgical procedures for all in-hospital care, available nationwide since 1987, as well as outpatient specialist care with nationwide coverage since $2001 .{ }^{16}$ Eligible cases of neurofibromatosis (NF1, NF2, and schwannomatosis), TSC, von Hippel-Lindau disease (VHL), ataxia telangiectasia, and other unspecified phacomatoses were identified through the Patient Register using the International Statistical Classification of Diseases and Related Health Problems, Ninth and Tenth Revisions (ICD-9 and ICD-10), as specified in Table 1. Using data from the Patient Register gave us a unique opportunity to investigate these rare outcomes in a large population with sufficient statistical power. Included cases were individuals born in Sweden from 1960 who were still alive in 1987, when the ICD-9 version was introduced. As is evident from Table 1, the ICD codes do not always distinguish between specific subtypes of phacomatoses; hence, it was not possible to specify the specific phacomatosis type for $44 \%$ of the cases. For neurofibromatosis, the classification in the Patient Register did not distinguish between NF1, NF2, and schwannomatosis, but the vast majority of neurofibromatosis is NF1 $(\sim 90 \%-95 \%) .{ }^{17}$

\section{Determination of heritability}

Cases were further classified as familial or nonfamilial. Firstand second-degree relatives of eligible individuals were identified through the Multigeneration Register, which includes the relationships between parents and their children for all individuals born since 1932 and resident in Sweden since 1960. ${ }^{18}$ Information on occurrence of genetic syndromes in first- and second-degree relatives was collected through linkage of the identified relatives with the Patient Register. To ensure that familial cases were not classified as nonfamilial, we defined cases as familial if any genetic syndrome was identified in a relative. This conservative approach was used as some of the diagnostic information in the Patient Register was coded according to earlier, less precise, ICD versions. Thus, for the period 1964-1967, ICD-7 code 759, and for 1968-1986, ICD-8 codes $759,759.86,759.87,743.40$ were used to define familial occurrence of phacomatosis, whereas from 1987 onward, the ICD-9 and ICD-10 codes listed in Table 1 were used.

To assess potential changes in completeness of case identification and classification into familial vs nonfamilial cases during the study period, we investigated the distribution of age at diagnosis according to birth cohort and heritability, frequency of identified familial and nonfamilial cases per calendar year, and the distribution of age at death among cases according to birth cohort. No apparent trends were observed.

\section{Control selection}

Ten controls per case were randomly selected from the eligible population, matched to the case on sex, birth year, and residence in Sweden at date of case detection. ${ }^{15}$ An additional eligibility criterion was that controls should not have a first- or second-degree relative diagnosed with a genetic syndrome.

\section{Parental age and covariates}

Information about parents' birth years and countries of birth was extracted from the Multigeneration Register. Parental education and parental country of birth were considered potential confounders. Information about parental education was collected from registers available at Statistics Sweden. We used educational information from the census conducted in 1970 and yearly information from the Longitudinal Integration Database for Health Insurance and Labour Market Studies (LISA) from 1990.

\section{Statistical analyses}

Conditional logistic regression was used to estimate the crude association between parental age and the risk of nonfamilial and familial phacomatoses in offspring. The results were later adjusted for parental education, parental country of birth, and mutually adjusted for maternal and paternal ages. Analyses were conducted for neurofibromatosis alone and all other phacomatoses combined. Sensitivity analyses were performed where the population was restricted to persons born 1987 or later. In 1987, the Patient Register became available nationwide and ICD-9 was introduced, which is likely to contribute to a complete case identification and thereby less misclassification of heritability. Parental education was defined as the highest achieved maternal/paternal educational level and was categorized into the following: low, elementary school; intermediate, high school or apprenticeship; and high, university or postgraduate. Maternal/paternal country of birth was categorized into Nordic and non-Nordic countries, where parental country of birth was considered Nordic if both parents were born in a Nordic country. The analyses were conducted using Stata statistical software version 13 (StataCorp, College Station, TX, USA) and SAS statistical software version 9.3 (SAS Institute, Inc, Cary, NC, USA).

\section{Results}

In total, we identified 4625 phacomatoses cases and 46250 matched controls. Distribution of phacomatoses subtypes was as follows: 2089 neurofibromatosis, of which 61\% were nonfamilial; and 2536 other subtypes combined, of which $87 \%$ were nonfamilial. More than $45 \%$ of the cases were 
diagnosed with neurofibromatosis. Less than $0.5 \%$ of the cases and controls had missing data on parental education and these were excluded from the analyses. The distributions of parental country of birth and parental education were similar among cases and controls. The demographic characteristics of cases and controls are summarized in Table 2 .

Table 3 illustrates the association between paternal and maternal ages at birth and prevalence of familial and nonfamilial neurofibromatosis in offspring. In crude analyses, for offspring of fathers aged 35-39 years, compared with offspring of fathers aged 25-29 years, the odds ratio (OR) was estimated at 1.44 (95\% CI 1.21-1.71), increasing to OR $=1.72$ (95\% CI 1.42-2.08) in offspring of fathers aged $\geq 40$ years. An elevated risk estimate was also observed for offspring of mothers aged 35-39 years (OR $=1.23[95 \%$
CI 1.02-1.49]). We found no indication of associations between advanced paternal or maternal age and risk of familial neurofibromatosis. In adjusted analyses, compared with offspring of fathers aged 25-29 years, elevated risk estimates were observed for nonfamilial neurofibromatosis among offspring of older fathers; in the category of paternal age 35-39 years, the OR was estimated at 1.43 (95\% CI 1.16-1.74), increasing to OR $=1.74$ (95\% CI 1.38-2.19) in offspring of fathers aged $\geq 40$ years. No associations were observed between advanced paternal age and risk of familial neurofibromatosis. Furthermore, there was no consistent association between advanced maternal age and neurofibromatosis in offspring.

Results for other nonfamilial phacomatoses were similar but less pronounced (Table 4). For offspring of fathers

Table 2 Descriptive characteristics of study participants born since 1960

\begin{tabular}{|c|c|c|c|c|c|c|c|c|}
\hline Characteristics & NF & $\begin{array}{l}\text { Nonfamilial } \\
\text { NF }\end{array}$ & $\begin{array}{l}\text { Familial } \\
\text { NF }\end{array}$ & $\begin{array}{l}\text { NF- } \\
\text { matched } \\
\text { controls }\end{array}$ & $\begin{array}{l}\text { Other } \\
\text { phacomatoses } \\
\text { combined }\end{array}$ & $\begin{array}{l}\text { Nonfamilial } \\
\text { phacomatoses }\end{array}$ & $\begin{array}{l}\text { Familial } \\
\text { phacomatoses }\end{array}$ & $\begin{array}{l}\text { Other } \\
\text { phacomatoses- } \\
\text { matched controls }\end{array}$ \\
\hline $\begin{array}{l}\text { Number of } \\
\text { participants, } n \text { (\%) }\end{array}$ & 2089 & $1283(6 \mid)$ & $806(39)$ & 20890 & 2536 & $2195(87)$ & $34 \mid(13)$ & 25360 \\
\hline $\begin{array}{l}\text { Paternal age in } \\
\text { years, mean, SD }\end{array}$ & $32.13,0.14$ & $32.61,0.19$ & $31.35,0.21$ & $31.40,0.04$ & $31.37,0.13$ & $3 I .4 I, 0.13$ & $31.17,0.35$ & $31.14,0.04$ \\
\hline $\begin{array}{l}\text { Maternal age in } \\
\text { years, mean, SD }\end{array}$ & $28.71,0.12$ & $29.02,0.15$ & $28.22,0.18$ & $28.52,0.04$ & $28.27,0.11$ & $28.28,0.11$ & $28.25,0.28$ & $28.19,0.03$ \\
\hline \multicolumn{9}{|l|}{ Sex, n (\%) } \\
\hline Male & $105 \mid(50)$ & $657(5 \mathrm{I})$ & $394(49)$ & $10510(50)$ & $1348(53)$ & $1169(53)$ & $179(52)$ & $13480(53)$ \\
\hline Female & $1038(50)$ & $626(49)$ & $4 \mid 2(5 \mid)$ & $10380(50)$ & II 88 (47) & $1026(47)$ & $162(48)$ & I I 880 (47) \\
\hline \multicolumn{9}{|c|}{ Parental education level, n (\%) } \\
\hline Low $^{2}$ & $283(14)$ & $164(13)$ & $119(15)$ & $2175(10)$ & $262(10)$ & $230(11)$ & $32(9)$ & $2530(10)$ \\
\hline Intermediate ${ }^{\mathrm{b}}$ & $105 \mid(50)$ & $568(44)$ & $483(60)$ & $9603(46)$ & $1183(47)$ & $1014(46)$ & $169(50)$ & $11925(47)$ \\
\hline Highc & $749(36)$ & $546(43)$ & $203(25)$ & $9083(44)$ & $1089(43)$ & $950(43)$ & $139(4 \mid)$ & $10847(43)$ \\
\hline Missing & $6(0)$ & $5(0)$ & $I(0)$ & $29(0)$ & $2(0)$ & $\mathrm{I}(0)$ & I (0) & $58(0)$ \\
\hline \multicolumn{9}{|c|}{ Parental country of birth, ${ }^{\mathrm{d}} \mathrm{n}(\%)$} \\
\hline Nordic countries & $1809(87)$ & $1098(86)$ & $711(88)$ & $18329(88)$ & $2261(89)$ & $1962(89)$ & $299(88)$ & $22512(89)$ \\
\hline $\begin{array}{l}\text { Non-Nordic } \\
\text { countries }\end{array}$ & $280(13)$ & $185(14)$ & $95(12)$ & $2561(12)$ & $275(11)$ & $233(11)$ & $42(12)$ & $2848(\mathrm{II})$ \\
\hline Missing & - & - & - & - & - & - & - & - \\
\hline \multicolumn{9}{|l|}{ Birth year, n (\%) } \\
\hline $1960-1969$ & $355(17)$ & $240(19)$ & $115(14)$ & $3550(17)$ & $398(16)$ & $329(15)$ & $69(20)$ & $3980(16)$ \\
\hline $1970-1979$ & $370(18)$ & $225(17)$ & $145(18)$ & $3700(18)$ & $469(18)$ & $408(19)$ & $61(18)$ & $4690(18)$ \\
\hline $1980-1989$ & $458(22)$ & $279(22)$ & $179(22)$ & $4580(22)$ & $860(34)$ & $775(35)$ & $85(25)$ & $8600(34)$ \\
\hline $1990-1999$ & $497(24)$ & $304(24)$ & $193(24)$ & $4970(24)$ & $635(25)$ & $543(25)$ & $92(27)$ & $6350(25)$ \\
\hline $2000-2010$ & 409 (19) & $235(18)$ & $174(22)$ & 4090 (19) & $174(7)$ & $140(6)$ & $34(10)$ & $1740(7)$ \\
\hline \multicolumn{9}{|c|}{ Type of phacomatosis, n (\%) } \\
\hline $\begin{array}{l}\text { Tuberous sclerosis } \\
\text { complex }\end{array}$ & - & - & - & - & 376 & $292(78)$ & $84(22)$ & - \\
\hline $\begin{array}{l}\text { von Hippel-Lindau } \\
\text { disease }\end{array}$ & - & - & - & - & 84 & $36(43)$ & $48(57)$ & - \\
\hline $\begin{array}{l}\text { Ataxia } \\
\text { telangiectasia }\end{array}$ & - & - & - & - & 31 & $22(7 \mathrm{I})$ & $9(29)$ & - \\
\hline Others & - & - & - & - & 2045 & $1845(90)$ & $200(10)$ & - \\
\hline
\end{tabular}

Notes: ${ }^{\text {LLow }}=$ elementary school; ' Intermediate = high school or apprenticeship; 'High = university or postgraduate university (parental education was defined by the highest

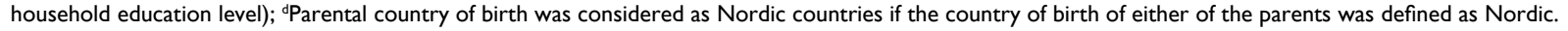
Abbreviation: NF, neurofibromatosis. 

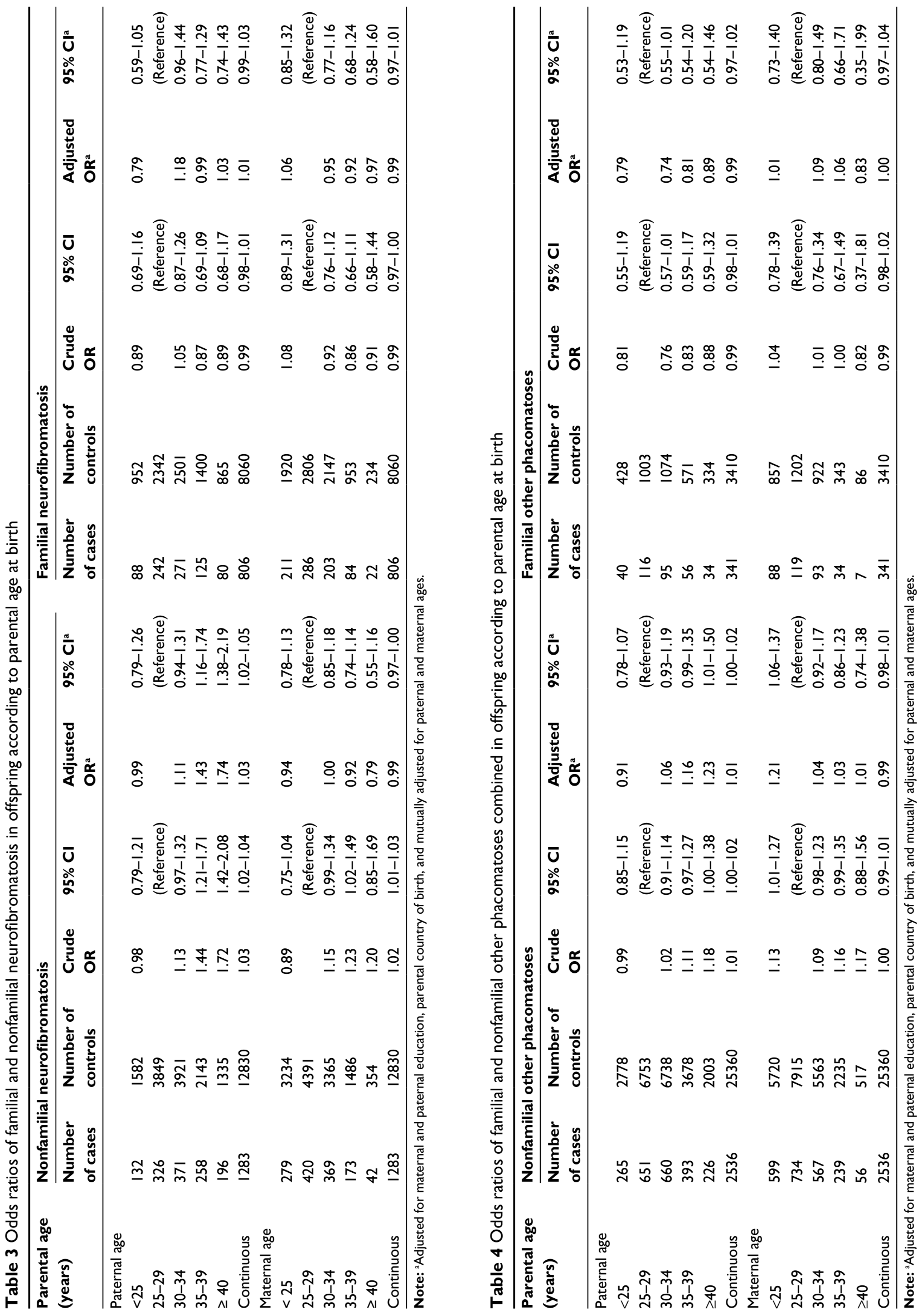
aged $\geq 40$ years, compared with offspring of fathers aged 25-29 years, the crude OR was estimated at 1.18 (95\% CI 1.00-1.38), whereas the adjusted OR was estimated at 1.23 (95\% CI 1.01-1.50). An elevated risk estimate was also observed for offspring of mothers aged $<25$ years (crude $\mathrm{OR}=1.13$ [95\% CI 1.01-1.27]; adjusted OR $=1.21$ [95\% CI 1.06-1.37]), but with no consistent trend. We found no indication of associations between advanced paternal or maternal age and risk of other familial phacomatoses.

Table S1 summarizes the demographic characteristics of cases and controls included in the sensitivity analyses performed on the subjects born in 1987 or later for whom we expect a complete identification of familial cases. The associations between advanced paternal age and risk of nonfamilial neurofibromatosis, as well as other nonfamilial phacomatoses, were more pronounced in analyses restricted to subjects born since 1987 (Tables S2 and S3). As in the main analyses, no association was observed between advanced paternal age and risk of familial neurofibromatosis or other familial phacomatoses. Moreover, no association was observed with advanced maternal age in adjusted results, whereas an indication was found in crude analyses for nonfamilial neurofibromatosis (Tables S2 and S3).

\section{Discussion}

The results of this study demonstrate that advanced paternal age is associated with an increased risk of nonfamilial phacomatoses in children, with a clear trend with increasing paternal age. The estimated effect was more pronounced for neurofibromatosis than for other types of phacomatoses. For nonfamilial neurofibromatosis, no association was observed with maternal age, but there was an indication that offspring of young mothers had an increased risk of nonfamilial phacomatoses other than neurofibromatosis, but with no consistent trend with maternal age. No association was observed between parental age and familial phacomatoses in offspring.

Germ cell mutations result from errors in DNA replication, and, compared with oogenesis, spermatogenesis consists of more cell divisions and consequently more DNA replications. Therefore, the de novo mutation rate in the male germ line is higher than that in the female germ line, and the mutation frequency increases with advancing age. ${ }^{19-21}$ In addition, there is evidence that the majority of de novo NF1 and NF2 mutations are of paternal origin, ${ }^{22,23}$ which supports our findings of an increased risk of de novo neurofibromatosis associated with advanced paternal, but not maternal, age. Our findings are consistent with an increasing rate of de novo mutations in the NF1 and NF2 genes in spermatozoa of older fathers.
Moreover, most of the germ line mutations involved in various subtypes of phacomatosis belong to the Ras pathway genes, which are hypothesized to confer a selective advantage in terms of de novo mutations for the male gamete. ${ }^{24}$ However, it has also been reported that young maternal age is related to some genetic abnormalities and congenital malformations, which could be due to disturbances during oocyte maturation. ${ }^{25-27}$ Moreover, there is evidence that the origin of de novo whole-gene deletion of $N F 1$ is predominantly maternal. ${ }^{28}$

Our findings for neurofibromatosis are in line with the results of the study by Liu et al, ${ }^{8}$ although their substantially smaller study did not clearly distinguish between effects of paternal and maternal ages. A few previous smaller studies also support these findings. ${ }^{7,10,11,29-31}$ For other subtypes of phacomatoses, very few data are available and these do not indicate an effect of parental age. However, these studies included few subjects, and analyses were limited to comparison of the mean paternal and maternal ages. ${ }^{32-34}$ Our study represents the largest phacomatosis population to date and includes various subtypes of phacomatoses. We used population-based register data for both case and control recruitment, as well as for collection of information about familial conditions, parental age, and potential confounding factors, which limits selection and recall bias. Parental education and parental country of birth were included in the analyses as potential confounders, as well as mutual adjustment for maternal and paternal ages, respectively, which was not done in most of the previous studies. As such, we minimized the possibility that the observed associations were due to confounding by these factors.

This study has also some limitations. It was not possible to distinguish between specific phacomatosis subtypes for almost half of the cases due to limitations in the ICD coding system used in the Patient Register. The coding allowed us to identify neurofibromatosis, but we could not separate the specific subtypes of neurofibromatosis, although the majority is likely to be NF1 ( 95\%). Moreover, cases were considered familial if their relatives were diagnosed with any type of genetic syndromes, again due to the difficulties in specifying the phacomatosis subtypes. Access to diagnostic information from hospital discharges and outpatient visits gave us a unique opportunity to study these rare outcomes in a large population with sufficient statistical power and to determine whether a case was familial or sporadic. There is, however, a possibility that some phacomatosis patients could not be identified, especially in the early study period when the Patient Register was not yet implemented nationwide. This would lead to nondifferential misclassification of the outcome, which could bias the risk estimates toward the null. However, the 
studied outcomes are very rare; thus, the magnitude of such bias is likely to be negligible. Of more concern is the potential misclassification of familial cases as nonfamilial, which would dilute the estimates of the effect of paternal age on the sporadic occurrence of phacomatoses. Restricting the analyses to cases born since the coverage of the Patient Register had become nationwide resulted in slightly stronger risk estimates associated with paternal age. Thus, our findings are likely to be conservative estimates of the effect of paternal age.

\section{Conclusion}

In conclusion, the present study provides strong evidence that advanced paternal age is associated, in the offspring, with a higher prevalence of nonfamilial phacomatoses that are predisposing to nervous system tumors, with the strongest effects observed for neurofibromatosis. Our findings did not indicate any effect of advanced maternal age on these outcomes.

\section{Acknowledgments}

The study was funded by the Swedish Cancer Society (contract 16-0406). The funder had no role in the design and conduct of the study, analysis and interpretation of the data, or preparation or approval of the manuscript.

\section{Disclosure}

The authors report no conflicts of interest in this work.

\section{References}

1. Garber JE, Offit K. Hereditary cancer predisposition syndromes. J Clin Oncol. 2005;23(2):276-292.

2. Kerrison JB, Newman NJ. The phacomatoses. Neurosurg Clin N Am. 1999;10(4):775-787, x.

3. Melean G, Sestini R, Ammannati F, Papi L. Genetic insights into familial tumors of the nervous system. Am J Med Genet C Semin Med Genet. 2004;129C(1):74-84.

4. Johansson G, Andersson U, Melin B. Recent developments in brain tumor predisposing syndromes. Acta Oncol. 2016;55(4):401-411.

5. Evans DG, Howard E, Giblin C, et al. Birth incidence and prevalence of tumor-prone syndromes: estimates from a UK family genetic register service. Am J Med Genet A. 2010;152A(2):327-332.

6. Northrup H, Krueger DA; International Tuberous Sclerosis Complex Consensus Group. Tuberous sclerosis complex diagnostic criteria update: recommendations of the 2012 Iinternational Tuberous Sclerosis Complex Consensus Conference. Pediatr Neurol. 2013;49(4):243-254.

7. Snajderova M, Riccardi VM, Petrak B, et al. The importance of advanced parental age in the origin of neurofibromatosis type 1. Am J Med Genet A. 2012;158A(3):519-523.

8. Liu Q, Zoellner N, Gutmann DH, Johnson KJ. Parental age and neurofibromatosis type 1: a report from the NF1 Patient Registry Initiative. Fam Cancer. 2015;14(2):317-324.

9. Crow JF. The origins, patterns and implications of human spontaneous mutation. Nat Rev Genet. 2000;1(1):40-47.

10. Bunin GR, Needle M, Riccardi VM. Paternal age and sporadic neurofibromatosis 1: a case-control study and consideration of the methodologic issues. Genet Epidemiol. 1997;14(5):507-516.
11. Dubov T, Toledano-Alhadef H, Bokstein F, Constantini S, Ben-Shachar $\mathrm{S}$. The effect of parental age on the presence of de novo mutations - lessons from neurofibromatosis type I. Mol Genet Genomic Med. 2016;4(4):480-486.

12. Yip BH, Pawitan Y, Czene K. Parental age and risk of childhood cancers: a population-based cohort study from Sweden. Int J Epidemiol. 2006;35(6): 1495-1503.

13. Johnson KJ, Cullen J, Barnholtz-Sloan JS, et al. Childhood brain tumor epidemiology: a brain tumor epidemiology consortium review. Cancer Epidemiol Biomarkers Prev. 2014;23(12):2716-2736.

14. Johnson KJ, Carozza SE, Chow EJ, et al. Parental age and risk of childhood cancer: a pooled analysis. Epidemiology. 2009;20(4):475-483.

15. Ludvigsson JF, Almqvist C, Bonamy AKE, et al. Registers of the Swedish total population and their use in medical research. Eur J Epidemiol. 2016;31(2):125-136.

16. Ludvigsson JF, Andersson E, Ekbom A, et al. External review and validation of the Swedish national inpatient register. BMC Public Health. 2011;11:450.

17. Kresak JL, Walsh M. Neurofibromatosis: a review of NF1, NF2, and schwannomatosis. J Pediatr Genet. 2016;5(2):98-104.

18. Ekbom A. The Swedish Multi-generation Register. Methods Mol Biol. 2011;675:215-220.

19. Rolf C, Nieschlag E. Reproductive functions, fertility and genetic risks of ageing men. Exp Clin Endocrinol Diabetes. 2001;109(2):68-74.

20. Kovac JR, Addai J, Smith RP, Coward RM, Lamb DJ, Lipshultz LI. The effects of advanced paternal age on fertility. Asian J Androl. 2013;15(6): 723-728.

21. Jung A, Schuppe HC, Schill WB. Are children of older fathers at risk for genetic disorders? Andrologia. 2003;35(4):191-199.

22. Kluwe L, Mautner V, Parry DM, et al. The parental origin of new mutations in neurofibromatosis 2. Neurogenetics. 2000;3(1):17-24.

23. Stephens K, Kayes L, Riccardi VM, Rising M, Sybert VP, Pagon RA. Preferential mutation of the neurofibromatosis type 1 gene in paternally derived chromosomes. Hum Genet. 1992;88(3):279-282.

24. Goriely A, McGrath JJ, Wilkie AOM, Malaspina D. "Selfish spermatogonial selection": a novel mechanism for the association between advanced paternal age and neurodevelopmental disorders. Am J Psychiatry. 2013;170(6):599-608.

25. Croen LA, Shaw GM. Young maternal age and congenital malformations: a population-based study. Am J Public Health. 1995;85(5):710-713.

26. Mikkelsen M. Downs syndrome at young maternal age - cytogenetical and genealogical study of 81 families. Ann Hum Genet. 1967;31:51.

27. Baird DT, Collins J, Egozcue J, et al. Fertility and ageing. Hum Reprod Update. 2005;11(3):261-276.

28. Upadhyaya M, Ruggieri M, Maynard J, et al. Gross deletions of the neurofibromatosis type 1 (NF1) gene are predominantly of maternal origin and commonly associated with a learning disability, dysmorphic features and developmental delay. Hum Genet. 1998;102(5):591-597.

29. Riccardi VM, Dobson CE 2nd, Chakraborty R, Bontke C. The pathophysiology of neurofibromatosis: IX. Paternal age as a factor in the origin of new mutations. Am J Med Genet. 1984;18(1):169-176.

30. Takano T, Kawashima T, Yamanouchi Y, et al. Genetics of neurofibromatosis 1 in Japan: mutation rate and paternal age effect. Hum Genet. 1992;89(3):281-286.

31. North K. Neurofibromatosis type 1: review of the first 200 patients in an Australian clinic. J Child Neurol. 1993;8(4):395-402.

32. Sampson JR, Scahill SJ, Stephenson JB, Mann L, Connor JM. Genetic aspects of tuberous sclerosis in the west of Scotland. J Med Genet. 1989;26(1):28-31.

33. Maher ER, Iselius L, Yates JR, et al. Von Hippel-Lindau disease: a genetic study. J Med Genet. 1991;28(7):443-447.

34. Huson SM, Compston DA, Clark P, Harper PS. A genetic study of von Recklinghausen neurofibromatosis in south east Wales. I. Prevalence, fitness, mutation rate, and effect of parental transmission on severity. $J$ Med Genet. 1989;26(11):704-711. 


\section{Supplementary materials}

Table SI Descriptive characteristics of study participants born since 1987

\begin{tabular}{|c|c|c|c|c|c|c|c|c|}
\hline Characteristics & NF & $\begin{array}{l}\text { Nonfamilial } \\
\text { NF }\end{array}$ & $\begin{array}{l}\text { Familial } \\
\text { NF }\end{array}$ & $\begin{array}{l}\text { NF- } \\
\text { matched } \\
\text { controls }\end{array}$ & $\begin{array}{l}\text { Other } \\
\text { phacomatoses } \\
\text { combined }\end{array}$ & $\begin{array}{l}\text { Nonfamilial } \\
\text { phacomatoses }\end{array}$ & $\begin{array}{l}\text { Familial } \\
\text { phacomatoses }\end{array}$ & $\begin{array}{l}\text { Other } \\
\text { phacomatoses- } \\
\text { matched controls }\end{array}$ \\
\hline $\begin{array}{l}\text { Number of } \\
\text { participants (\%) }\end{array}$ & 1074 & $644(60)$ & $430(40)$ & 10740 & 1169 & $1010(86)$ & $159(14)$ & 11690 \\
\hline $\begin{array}{l}\text { Paternal age in } \\
\text { years, mean, SD }\end{array}$ & $\begin{array}{l}33.14 \\
0.19\end{array}$ & $33.84,0.27$ & $\begin{array}{l}32.09 \\
0.28\end{array}$ & $\begin{array}{l}32.42 \\
0.06\end{array}$ & $32.48,0.18$ & $32.45,0.19$ & $32.67,0.49$ & $32.00,0.06$ \\
\hline $\begin{array}{l}\text { Maternal age in } \\
\text { years, mean, SD } \\
\text { Sex, } \mathrm{n}(\%)\end{array}$ & $\begin{array}{l}29.69 \\
0.16\end{array}$ & $30.16,0.21$ & $\begin{array}{l}28.97 \\
0.24\end{array}$ & $\begin{array}{l}29.65 \\
0.05\end{array}$ & $29.31,0.15$ & $29.26,0.16$ & $29.59,0.39$ & $29.09,0.05$ \\
\hline Male & $578(54)$ & $365(57)$ & $213(50)$ & $5780(54)$ & $643(55)$ & $559(55)$ & $84(53)$ & $6430(55)$ \\
\hline Female & $496(46)$ & $279(43)$ & $217(50)$ & $4960(46)$ & $526(45)$ & $45 I(45)$ & $75(47)$ & $5260(45)$ \\
\hline \multicolumn{9}{|c|}{ Parental education level, n (\%) } \\
\hline Low $^{a}$ & $69(6)$ & $38(6)$ & $31(7)$ & $402(4)$ & $54(5)$ & $48(5)$ & $6(4)$ & $47 I(4)$ \\
\hline Intermediate ${ }^{b}$ & $547(5 \mathrm{I})$ & $278(43)$ & $269(63)$ & $4757(44)$ & $522(45)$ & $447(44)$ & $75(47)$ & $5399(46)$ \\
\hline $\mathrm{High}^{c}$ & $456(43)$ & $326(5 \mathrm{I})$ & $130(30)$ & $5570(52)$ & $592(5 \mathrm{I})$ & $514(5 \mathrm{I})$ & $78(49)$ & $5801(50)$ \\
\hline Missing & $2(0)$ & $2(0)$ & - & II (0) & I $(0)$ & I (0) & - & $19(0)$ \\
\hline \multicolumn{9}{|c|}{ Parental country of birth, ${ }^{d} \mathrm{n}(\%)$} \\
\hline Nordic countries & $878(82)$ & $515(80)$ & $363(84)$ & $8855(82)$ & $990(85)$ & $863(85)$ & $127(80)$ & $9879(85)$ \\
\hline $\begin{array}{l}\text { Non-Nordic } \\
\text { countries }\end{array}$ & $196(18)$ & $129(20)$ & $67(16)$ & $1885(18)$ & $179(15)$ & $147(15)$ & $32(20)$ & $1811(15)$ \\
\hline \multicolumn{9}{|l|}{ Birth year, n (\%) } \\
\hline $1987-1989$ & $168(16)$ & $105(16)$ & $63(15)$ & $1680(16)$ & $360(31)$ & $327(32)$ & $33(21)$ & $3600(31)$ \\
\hline $1990-1999$ & $497(46)$ & $304(47)$ & $193(45)$ & $4970(46)$ & $635(54)$ & $543(54)$ & $92(58)$ & $6350(54)$ \\
\hline $2000-2010$ & $409(38)$ & 235 & $174(40)$ & $4090(38)$ & $174(15)$ & $140(14)$ & $34(21)$ & $1740(15)$ \\
\hline \multicolumn{9}{|c|}{ Type of phacomatoses, n (\%) } \\
\hline $\begin{array}{l}\text { Tuberous } \\
\text { sclerosis complex }\end{array}$ & - & - & - & - & 220 & $164(75)$ & $56(25)$ & - \\
\hline $\begin{array}{l}\text { von Hippel- } \\
\text { Lindau disease }\end{array}$ & - & - & - & - & 29 & $6(2 I)$ & $23(79)$ & - \\
\hline $\begin{array}{l}\text { Ataxia } \\
\text { telangiectasia }\end{array}$ & - & - & - & - & 12 & $7(58)$ & $5(42)$ & - \\
\hline Others & - & - & - & - & 908 & $833(92)$ & $75(8)$ & - \\
\hline
\end{tabular}

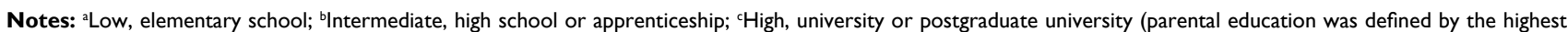
household education level); ${ }^{~ P a r e n t a l}$ country of birth was considered as Nordic countries if the country of birth of either of the parents was defined as Nordic.

Abbreviation: NF, neurofibromatosis. 


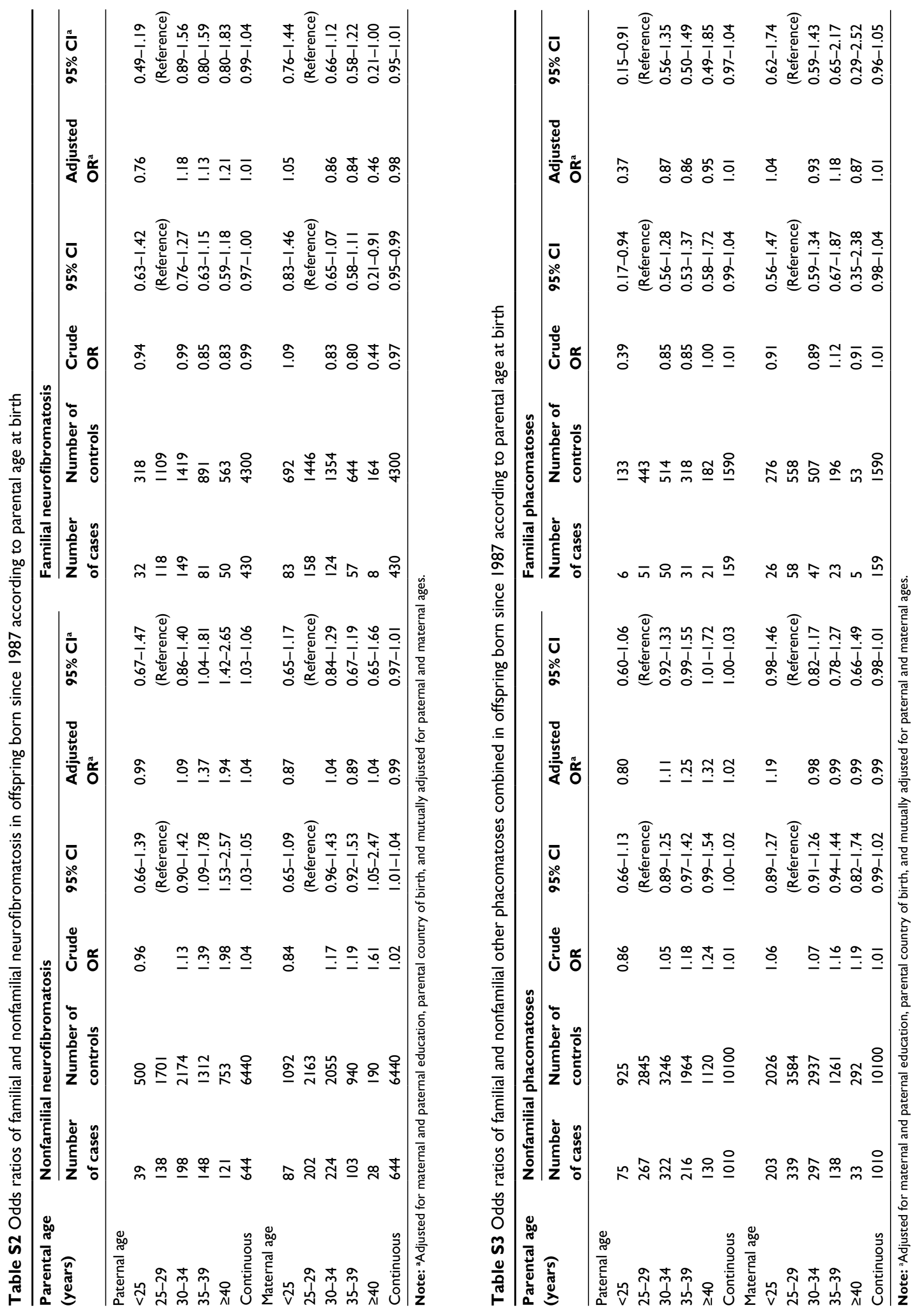




\section{Publish your work in this journal}

Clinical Epidemiology is an international, peer-reviewed, open access, online journal focusing on disease and drug epidemiology, identification of risk factors and screening procedures to develop optimal preventative initiatives and programs. Specific topics include: diagnosis, prognosis, treatment, screening, prevention, risk factor modification,

Submit your manuscript here: https://www.dovepress.com/clinical-epidemiology-journal systematic reviews, risk and safety of medical interventions, epidemiology and biostatistical methods, and evaluation of guidelines, translational medicine, health policies and economic evaluations. The manuscript management system is completely online and includes a very quick and fair peer-review system, which is all easy to use. 